Acta regionalia et environmentalica 1

Nitra, Slovaca Universitas Agriculturae Nitriae, 2014, p. 1-4

\title{
CHANGES TO THE BAKOMI RESERVOIR
}

\author{
Daniel KUBINSKÝ1*, Karol WEIS', Milan LEHOTSKÝ2, Jakub FUSKA ${ }^{3}$ \\ 'Matej Bel University, Banská Bystrica, Slovak Republic \\ ${ }^{2}$ Institute of Geography, Slovak Academy of Sciences, Slovak Republic \\ ${ }^{3}$ Slovak University of Agriculture in Nitra, Slovak Republic
}

\begin{abstract}
This article is focused on the analysis and evaluation of the changes of the bottom of the Bakomi reservoir, the total volume of the reservoir, ecosystems, as well as changes in the riparian zone of the Bakomi reservoir (situated in the central Slovakia). Changes of the water component of the reservoir were subject to the deposition by erosion-sedimentation processes, and were identified on the basis of a comparison of the present relief of the bottom of reservoir obtained from field measurements (in 2011) with the relief measurements of the bottom obtained from the 1971 historical maps, (i.e. over a period of 40 years). Changes of landscape structures of the riparian zone have been mapped for the time period of 1949-2013; these changes have been identified with the analysis of ortophotomaps and the field survey. There has been a significant rise of disturbed shores with low herb grassland. Over a period of 40 years, there has been a deposition of $667 \mathrm{~m}^{3}$ of sediments. The results showed that there were no significant changes in the local ecosystems of the Bakomi reservoir in comparison to the other reservoirs in the vicinity of Banská Štiavnica.
\end{abstract}

Keywords: bathymetric survey, lake morphology, land cover, riparian zone, reservoir

The Bakomi water reservoir is located in the Štiavnické Bane village near Banská Štiavnica. Bakomi and other water reservoirs in the vicinity of Banská Štiavnica are registered in the list of UNESCO World Heritage site. The creation of the Bakomi dates back to the years 1738-1740 (Hydroconsult, 1991). Erosion-sedimentation processes present in the reservoir basin caus the siltation of the Bakomi reservoir, these changes result in the changes of the terrain and reservoir bottom morphology. This process occurs worldwide and it cannot be stopped (Holubová, 1998). Riparian zone is the specific part of the reservoir, it is a three-dimensional entity of interactions between aquatic and terrestrial natural systems (Gregory et al., 1991). It is often referred to as a riparian or buffer zone (Hupp and Osterkamp, 1996). Riparian zone has a number of functions (Hansen et al., 2010) which are important in sustainable development of water bodies, and therefore it is necessary to explore and monitor the improvement of the water quality in the riparian zone, i.e. reduction of the excessive supply of nutrients and contaminants from the environment (slopes, roads, fields, etc.); reduction of the erosion and sediment supply; increase of the biodiversity; autoregulation and optimization of ecostructure and composition of the vegetation and animal communities. Changes in the riparian zone affect many organisms that live in aquatic environments and alter their ecosystems. The aim of this study is to evaluate the changes in the riparian zone and reservoir bottom of the Bakomi reservoir. A number of studies focus on reservoir bottom mapping and the study of changes caused by siltation with the use of the acoustic depth measuring (Boddy and Ganske, 2005; Ceylan et al., 2011; Chang et al., 2003; Childs et al., 2003; Jordan and Fonstad, 2005; Kress et al., 2005; Mcalister et al., 2013). Acoustic measurement methods were applied to reservoirs
(Yesuf et al., 2012) or to rivers (Awulachew, 2006; Elçi et al., 2009; Odhiambo and Boss, 2004; Yun and Cho, 2011). This method of research was not performed on the Bakomi site yet. The elevation measurements above mean sea level were performed in the "Baltic after adjustment" (Bpv) height system. This study does not deal with the characteristic of the Bakomi reservoir bottom sediment.

\section{Material and methods}

The methodology of field work was derived from the practice of analysing the degree of siltation in the water reservoir Ružín (Pauk et al., 1997) and the water reservoir Klenovec (Kočický et al., 2002) in Slovakia. The field research was undertaken on the Bakomi reservoir on $19^{\text {th }}$ October 2011. This research surveyed the depth of the Bakomi reservoir with the use of an acoustic device, where the dualbeam sonar was used. Measurements were taken directly from an inflatable boat using the acoustic equipment (717 Hummingbird the dual-beam sonar with $20^{\circ}$ or $60^{\circ}$ beams, stated accuracy of $\pm 10 \mathrm{~cm}$ ). The Echo Sounder device uses two different sound waves with frequencies of $200 \mathrm{kHz}$ and $83 \mathrm{kHz}$. To minimize the systematic measurement errors that are made during the research, the controlled referenced measurements were taken in set points with a leveling staff. About $8-10 \%$ of the measurements were controlled with this technique. The same methodology was used to measure the depth of several water reservoirs in the vicinity of Banská Štiavnica (Kubinský and Weis, 2011; Kubinský and Weis, 2012). Some of the reservoirs have been drained after the research due to the reconstruction by the Slovak Water Management Enterprise in the context of a long-term recovery program and maintenance; therefore the measurements were taken 
again to verify the accuracy of the method of selected points with the use of the teodolite. The average error equaled $\pm 3 \mathrm{~cm}$. Specific points for measurements were localized by GPS. Data regarding the depth of the bottom have been converted to absolute altitudes above sea level in places of the measurements. The basis for their determination was the already known absolute altitude above sea level of the water surface at the time of the measurements, and this has been identified from the difference of the current state of water levels and known elevation of the safety spillway. The absolute altitude above sea level of the water levels in both field measurements equaled $709.5 \mathrm{~m}$ above sea level.

The source of historical data was the historical map called „Bakomi reservoir - Štiavnické Bane" from June 1971 in the scale of $1: 500$. The plan was converted into digital form, then each contour line vectored in the software environment of the R2V Abble software. Each contour line has been assigned the value $Z$, giving absolute altitude above sea level of contour lines. Georeferencing of the vector to the S-JTSK Krrovák display was performed in the ArcGis software. The ortophotomaps have been chosen as a map reference in the known coordinate system (Eurosence, 2006). Georeferencing has been processed on the basis of the selection of appropriate dimensions which were clearly identified on both documents. Historical vector map and data obtained from the field measurements were connected to a single vector base map derived from the maps of the Slovak Republic in the scale of $1: 10000$, the status as of 2006 (maps ZM, 2006), and therefore other modeling only represented the changes to the surface in progress in the area of the water reservoir, not in its neighborhood.

The data from both sources (time frames) have been processed in the software environment Surfer 8, Golden Software. Grids with the size of the cell of $2 \times 2$ were generated with use of the interpolation by Kriging. Calculations of bottom relief changes in volume and visualization were also made in the software environment Surfer 8 - Golden Software. With the function of Grid/Volume..., the present state, that is, the Upper surface from the model, was deducted from the Lower surface, that is, the bottom surface of the model showing the past status. As stated in the manual for
Surfer (Surfer 8 user's guide, 2002), there are three procedures for determination of the volume:Trapezoidal Rule, Simpson's Rule, and Simpson's 3/8 Rule. The difference in the volume calculations with the three different methods lies in the precision of the volume calculations. If the values of these three calculations are not very different, the actual volume is assigned in the vicinity of these values.

Landscape structures in the riparian area were mapped in the ArcGis software. The riparian zone was set aside as a buffer with mean $20 \mathrm{~m}$ from the shoreline derived from ortophotomaps. The distance of $20 \mathrm{~m}$ was evaluated empirically based on the field research. Interpretation of the ortophotomaps from 2006 with subsequent addition of the data from field work to the present state (2013) together with retroactive interpretation of ortophotomaps from 1949 helped to create a map of land cover for two time horizons (1949 and 2013). The following categories were mapped: 1) water surface, 2) shores with low herb grassland, 3) permanent grassland, 4) scattered trees, 5) scrubs, 6), forest. With the analysis and synthesis of supportive results (changes of the bottom relief and changes in the riparian zone - the most influential environmental factors), we have acceded to the setting and identified changes in the ecosystems of the Bakomi reservoir.

\section{Results and discussion}

\section{Volume change}

The calculations were made in the Surfer software using digital elevation models of the reservoir based on the data from the years 1971 and 2011 (Fig. 1). The accuracy of the volume calculation was tested using three classical numerical integration algorithms in Surfer 8: Extended Trapezoidal Rule $\left(666 \mathrm{~m}^{3}\right)$, Extended Simpson's Rule $\left(670 \mathrm{~m}^{3}\right)$, Extended Simpson's 3/8 Rule $\left(665 \mathrm{~m}^{3}\right)$. With respect to the minimum deviation calculations, the resulting value was calculated as the average of all three calculations (Surfer 8 user's guide, 2002), and this was $667 \mathrm{~m}^{3}$. We observed that over a period of 40 years, there has been a significant volume of sediment buildup. The progress of the bottom is only partially modified

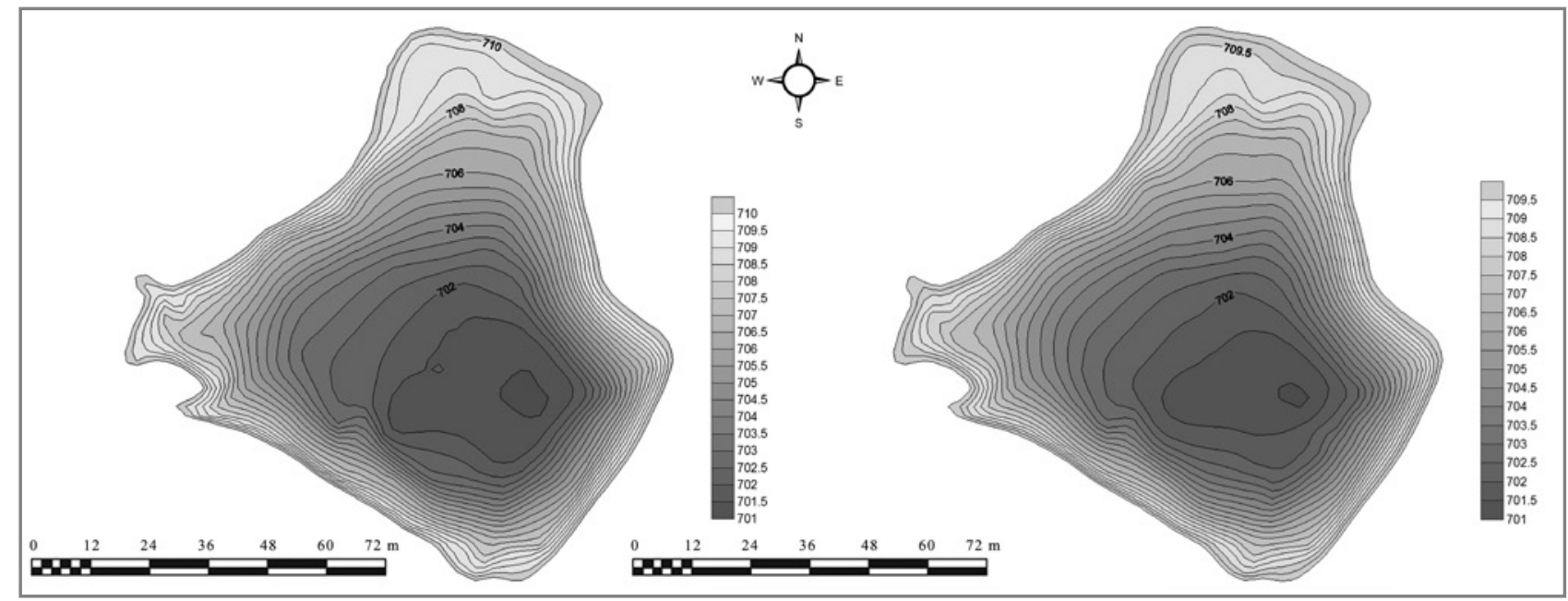

Figure 1 Bottom relief detail of Bakomi - the situation in 1971 (left) and 2011 (right) 
by shifting some of the contour lines. It is a tributary of the nearby water wells with matter that contains material with a slight inability of deposition. We state that over a period of 40 years, erosion-sedimentation processes did not cause changes that would be able to significantly disturb and alter the sub-ecosystems within the reservoir.

\section{Changes in the riparian zone}

In accordance with the analysis of the structure of the riparian zone detail (Fig. 2.), we observed the following:

1. The current use of reservoir is for tourist purposes, recreation, the support of water for mining purposes has disappeared, and Bakomi is used for the purposes of fish breeding. These are the reasons that affected the current significant increase in the share of the shore structure with low herb grassland in places with the original permanent grassland which decreased just as a result of anthropogenic impact (the rise of $2059 \mathrm{~m}^{2}$ ). Nowadays, these areas have the character of disturbed and eroded banks.

2. An increase in the area of forest cover near the reservoir on the southeast shore.

3. There was no change in the water area over a period of 64 years (1949-2013).

4 In the riparian zone, there was no building activity during a period of 64 years (1949-2013).

According to the comparison of changes in the topography of the bottom water reservoir in the time period of 1971-2011 and a comparison of changes in the riparian zone for the years 1949-2013 in the Bakomi

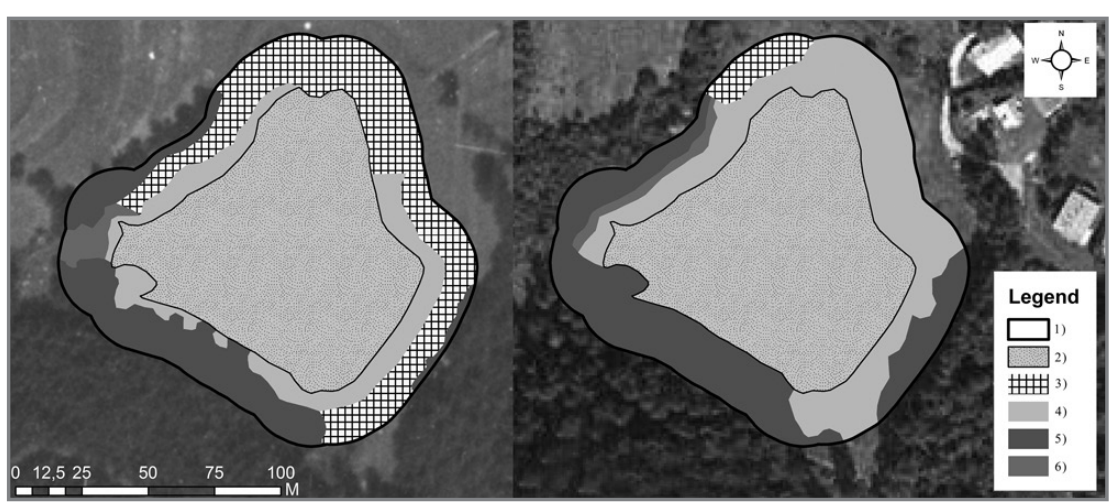

Figure 2 The riparian zone of Bakomi in 1949 (left) and 2013 (right); Explanatory 1. border of the riparian zone; 2 . water surface; 3 . permanent grassland; 4 . the shores with low herb grassland; 5 . forest; 6 ) scrubs

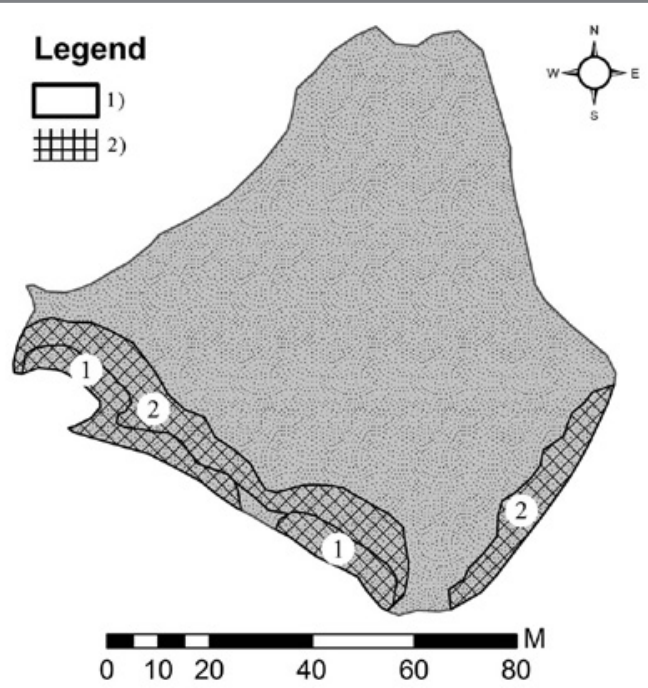

Figure 3 Identification of affected ecosystems in the Bakomi reservoir (1949-2013); explanatory notes: 1 . shore line; 2 . potentially affected ecosystems reservoir, we identify the following sub-ecosystems which were most affected during the period of 40 and 64 years respectively (Fig. 3).

Living conditions of the freshwater ecosystem in the Bakomi reservoir are characterized by a wide range of factors that decisively affect or limit the incidence and distribution of plants, animals and micro-organisms. The water temperature is a dynamic factor changing not only during the year, but also during the day.

Changes in water temperature and light regime are important ecological factors. Due to the increase in the tree structure in the reservoir's riparian zone that took place over a period of 64 years (1949-2013), the areas marked with the number 1 in Figure 3 were overshadowed, which may cause the change in the light and temperature regime. The presence of tree branches above these areas may result in the accumulation of organic matter dropped leaves and pine needles. Areas on exposed sites with dropped pine needles may therefore show a lower $\mathrm{pH}$. The $\mathrm{pH}$ value is one of the most sensitive indicators of equilibrium in natural waters. Areas marked with the number 2 in Figure 3 are overshadowed as a result of the increased tree growth, but they are not affected by the direct disposal of organic material (pine needles). The Bakomi reservoir provides living space for a number of organisms, for example phytoplankton (Aphanizomenon, Anabeana, Microcystis, Noctoc), algae causing water bloom (Claudophora, Chlorella, Euglena, Fragillaria, Melosira, Volvox), zooplankton (Crustacea, Copepoda, Rotifera and Cladocera). As Šinský (2010) states, the bottom of the water reservoir is inhabited by benthos (Diptera, Ephemenoptera, Hirudinea, Chironomidae, Mollusca, Trichoptera, Turbellaria). It can be concluded that the volume of sediment from the water tributary in the reservoir is at the minimum (we only observe a slight positive displacement of some of the contour lines), we suggest that there are no significant changes in the ecosystem of benthos. We only note slight changes in the ecological conditions of certain parts of the reservoir caused by light regime changes, and then the temperature regime with small impact to the organisms in the aquatic environment. 


\section{Conclusion}

The use of diachrony analysis of the bottom and the riparian zone of the Bakomi water reservoir indicates that there are changes taking place in its ecosystems. Changes of the bottom relief are subject to the erosion-sedimentation processes and consequently the accumulation of sediments in the reservoir and they are also affected by changes in the riparian zone. Changes in the riparian zone have a direct impact on a number of factors which affect the temperature and light regime of water, indirectly affecting the $\mathrm{pH}$ of the water, too. The synthesis of the two major factors, namely the change of landscape structure of the riparian zone and the relief change caused an alteration of the sub-ecosystems in the reservoir. The Bakomi reservoir is not only a technical landmark that is registered in the list of UNESCO World Heritage site, it is important to understand that this is a complex ecosystem which includes a small area of a relatively closed community of organisms. Despite the fact that there were no significant changes in the reservoir for the periods of 1949-2013 and 1971-2011 as to the morphometry of the reservoir bottom as well as the influence on the living conditions, it is our responsibility not to neglect another management of not only the riparian zone, but also the wider catchment area in order to ensure long-term sustainability and maintain the basic features of the Bakomi reservoir in optimal state.

\section{Acknowledgments}

The authors would like to thank the Slovak Water Management Enterprise for providing the historical map documentation and internal documents about the Bakomi reservoir, and Mgr. Rastislav Čech, who helped us with the field research. The study was created as a part of the UGA-I11-005-08 grant provided by the Faculty of Natural Sciences, Matej Bel University in Banská Bystrica, Slovakia.

\section{References}

AWULACHEW, S. B. 2006. Investigation of physical and bathymetric characteristics of Lakes Abaya and Chamo, Ethiopia, and their management implications. Lakes and Reservoirs : Research and Management, vol. 11, 2006, no. 3, p. 133-140.

BODDY, N. N. - GANSKE, L. 2005, Bathymetric Changes within Lake Zumbro of Olmsted County, Hydrologic Study of Produced by the Minnesota Pollution Control Agency, p. 1-21.

CEYLAN, A. - KARABORK, H. - EKOZOGLU, I. 2011. An analysis of bathymetric changes in altinapa reservoir. In: Carpathian Journal of Earth and Environmental Sciences, vol. 6, 2011, no. 2, p. 15-24. ELÇI, Ş. - BOR. A. - ÇALIŞKAN, A. 2009. Using numerical models and acoustic methods to predict reservoir sedimentation. In: Lake and Reservoir Management, vol. 25, 2009, no. 3, p. 297-306. GREGORY, S. V. - SWANSON, F. J. - MCKEE, W. A. - CUMMINS, K. W. 1991. An ecosystem perspective of riparian zones: focus on links between land and water. In: BioScience, 1991, no. 41, p. 540-550.

HANSEN, B. - REICH, P. - LAKE, P. S. - CAVAGNARO, T. 2010. Minimum width requirements for riparian zones to protect flowing waters and to conserve biodiversity: a review and recommendations. Report to the Office of Water, Department of Sustainability and Environment. Melborne (School of Biological Sciences, Monash University).
HOLUBOVÁ, K. 1998. Problémy systematického sledovania erózno-sedimentačných procesov $\mathrm{v}$ oblasti vodných diel. Bratislava : Výskumný ústav vodného hospodárstva.

HUPP, C. R. - OSTERKAMP, W. R. 1996. Riparian vegetation and fluvial geomorphic processes. In: Geomorphology, 1996, no. 14, p. 277-295.

HYDROCONSULT. 1991. Banskoštiavnická oblast'. Štúdia. Bratislava, 1991

CHANG, T. J. - BAYES, T. D. - MCKEEVER, S. 2003. Investigating reservoir sediment and watershed erosion using a geographical information system. In: Hydrological Processes, vol. 17, 2003, no. 5, p. 979-987.

CHILDS, J. R. - SNYDER, N. P. - HAMPTON, M. A. 2003. Bathymetric and geophysical surveys of Englebright Lake, Yuba-Nevada Counties, California, US Geological Survey OpenFile Report 03-383, p. 1-20.

JORDAN, D. C. - FONSTAD, M. A. 2005. Two Dimensional Mapping of River Bathymetry and Power using Aerial Photography and GIS on the Brazos River, Texas, Geocarto International, vol. 20, 2005, no. 3, p. 1-8.

KOČICKÝ, D. - PAUK, J. - KOČICKÁ, E. - GARGALOVIČ, R. VÁGÓ, Z. - VAZAN, V. - WEIS, K. 2002. Erózno-sedimentačné procesy na VN Klenovec. Banská Štiavnica : Esprit s. r. o, 155 pp. KRESS, W. H. - SEBREE, S. K. - LITTIN, G. R. - DRAIN, M. A. KLING, M. E. 2005. Comparison of Preconstruction and 2003 Bathymetric and Topographic Surveys of Lake McConaughy, Scientific Investigations Report 2005-5040. Published by U.S. Department of the Interior and U.S. Geological Survey, p. 1-27.

KUBINSKÝ, D. - WEIS, K. 2011. Zmeny retenčného objemu v priestore Halčianskeho tajchu. In: Acta hydrologica slovaca, SAV, roč. 12, 2011, č. 1, s. 59-64. ISSN 1335-6291.

KUBINSKÝ, D. - WEIS, K. 2012. Zmeny retenčného objemu v priestore Belianskej vodnej nádrže. In: Acta Hydrologica Slovaca, roč. 13, 2012, č. 1, s. 108-115. ISSN 1335-6291.

ODHIAMBO, B. K. - BOSS, S. K. 2004. Integrated echo sounder, GPS, and GIS for reservoir sedimentation studies: Examples from two Arkansas Lakes. In: Journal of the American Water Resources Association, vol. 40, 2004, no. 4, p. 981-997.

PAUK, J. - MIKLÓS, L. - TREMBOŠ, P. 1997. Vývoj eróznosedimentačných procesov vodnej nádrže Ružín. Čiastková správa D - Krajinnoekologické princípy ochrany nádrže pred zanášaním. Banská Štiavnica : ESPRIT, pp. 1-46.

SURFER 8 user's guide. 2002. Surfer ${ }^{\circledR}$. User's Guide. Contouring and 3D. Surface Mapping for. Scientists and Engineers, $640 \mathrm{p}$.

ŠINSKÝ, M. - TONČÍK, M. - PERHÁČOVÁ, Z. 2010: Tajch bakomi chodník o ekológii piargskych tajchov. Online at: http://www. stiavnickebane.ocu.sk/sk/lmage/sb_09/PANEL_EN_02.jpg

YESUF, H. M. - ALAMIREW, T. - MELESSE, A. M. - ASSEN, M. 2012. Bathymetric Mapping for Lake Hardibo in Northeast Ethiopia Using Sonar. In: International Journal of Water Sciences, vol. 1, 2012.

YUN, H.S. - CHO, J. M. 2011. Hydroacoustic application of bathymetry and geological survey for efficient reservoir management. In: Journal of the Korean Society of Surveying Geodesy Photogrammetry and Cartography, vol. 29, 2011, no. 2, p. 209-217.

\section{Contact address:}

RNDr. Daniel Kubinský, Matej Bel University, Faculty of Natural Sciences, Department of Biology and Ecology, Tajovského 40, Banská Bystrica, Slovakia, e-mail: posta@ dkubinsky.sk 